The U.S. invocation of the withdrawal clause came after consultation with European allies, who were reportedly dismayed when the Trump administration initially signaled its plans to withdraw in October 2018. ${ }^{13}$ By the time withdrawal was officially triggered in February 2019, U.S. allies in Europe were prepared for the decision. North Atlantic Treaty Organization (NATO) Secretary General Jens Stoltenberg said that the United States had announced its intent to withdraw "with the full support of all NATO Allies," and that, while ready to continue engaging with Russia, NATO was "preparing for a world without the INF Treaty." 14 Speaking frankly at the Munich Security Conference, Chancellor Angela Merkel of Germany described the collapse of the INF Treaty as "really bad news" that was "unavoidable" following "not decades, but years of violations of the terms of the treaty by Russia." 15 She observed that "it leaves us with a very interesting constellation: a treaty that was essentially designed for Europe, an arms reduction treaty that directly affects our security, has been cancelled by the United States of America and Russia .... And we are left sitting there." 16 She added that "we will obviously make every attempt to facilitate further arms reduction. The answer cannot be a blind arms race." 17

\title{
U.S. Military Undergoes Restructuring to Emphasize Cyber and Space Capabilities
} doi:10.1017/ajil.2019.39

Since entering office, President Trump has taken steps to restructure the U.S. military to raise the profile of both its cybersecurity and space capabilities. The administration has elevated U.S. Cyber Command to a Unified Combatant Command and has implemented policies signaling a shift toward a more offensive cybersecurity mindset. The administration has also begun the process of establishing a U.S. Space Command, as well as pursuing a plan to create a new branch of the military centered around space-related operations. Although this restructuring does not by itself implicate international law, it might do so if it results in operational changes.

On August 18, 2017, President Trump released a presidential memorandum directing the secretary of defense to establish U.S. Cyber Command as a Unified Combatant

13 See Galbraith, supra note 2, at 140.

14 NATO Press Release, Press Conference by NATO Secretary General Jens Stoltenberg Following the Meetings of NATO Defence Ministers (Feb. 13, 2019), at https://www.nato.int/cps/en/natohq/opinions_ 163394.htm [https://perma.cc/Y5DF-NX7M].

15 Office of the German Federal Chancellor Press Release, The Chancellor at the 55th Munich Security Conference (Feb. 16, 2019), at https://www.bundeskanzlerin.de/bkin-en/news/-all-of-us-together-will-beneeded-says-chancellor-1581236 [https://perma.cc/3TGA-ZCM4].

${ }^{16} \mathrm{Id}$.

${ }^{17} \mathrm{Id}$. 
Command. ${ }^{1}$ Unified Combatant Commands are unified across the different military service departments-Army, Navy, and Air Force—but are divided up either by geographic region or by function. ${ }^{2}$ Each "has a particular mission, and each may be involved in various operations or exercises." ${ }^{3}$ A long-standing congressional statute authorizes the president to create new Unified Combatant Commands and revise existing ones. ${ }^{4}$ One of these existing commands-U.S. Strategic Command-had housed Cyber Command as a subordinate unit since its creation in 2010.5 In 2016, in line with the objectives of the Obama administration, Congress instructed that Cyber Command should be made into its own Unified Combatant Command. ${ }^{6}$

On May 4, 2018, nearly a year after Trump's memorandum, Cyber Command was officially elevated to a Unified Combatant Command, becoming the tenth overall combatant command at the time. ${ }^{7}$ Cyber Command describes its mission as aiming "to direct, synchronize, and coordinate cyberspace planning and operations to defend and advance national interests in collaboration with domestic and international partners." ${ }^{8}$ More specifically:

The Command has three main focus areas: Defending the [Department of Defense (DoD) Information Network], providing support to combatant commanders for

\footnotetext{
${ }^{1}$ Donald J. Trump, Memorandum on Elevation of the United States Cyber Command to a Unified Combatant Command, 2017 Daily Comp. Pres. Doc. No. 577 (Aug. 18) [hereinafter Trump Cyber Memorandum]. Initiatives within the military to deal with cyber security issues existed as early as 1998, but it was not until 2008 that Secretary of Defense Robert Gates created an entity formally referred to as U.S. Cyber Command, which worked in collaboration with the National Security Agency. See U.S. Cyber Command, U.S. Cyber Command History, at https://www.cybercom.mil/About/History [https://perma.cc/9AWX-EPJZ].

2 There are currently six geographic commands-Africa, Central, European, Northern, Pacific, and Southernand, following the elevation of Cyber Command, four functional commands-Cyber, Strategic, Special Operations, and Transportation. See U.S. Dep't of Defense, Combatant Commands, at https://www.defense. gov/Our-Story/Combatant-Commands.

${ }^{3}$ Katie Lange, DoD's 9 Combatant Commands: What They Are, What They Do, DoDLive (Aug. 17, 2016), at http://www.dodlive.mil/2016/08/17/dods-9-combatant-commands-what-they-are-what-they-do [https:// perma.cc/6ZWF-UUGU] (adding that "operations are various phases of a war or military engagement; exercises are routine or non-routine training that tests strategies and explores the effects of warfare without actual combat").

${ }^{4} 10$ U.S.C. $\$ 161$ (a)(1), (b)(2)(B); see also Mark P. Nevitt, The Operational and Administrative Militaries, 52 GA. L. REV. _ (forthcoming 2019) (discussing the 1986 Goldwater-Nichols Act, which implemented the system of unified commands across the various forces within the military). Nevitt argues that congressional oversight tends to focus on the administrative branches of the military rather than on the conduct of the various commands, with the result that the executive branch has a great deal of autonomy with respect to these commands. See generally id.

${ }^{5}$ U.S. Cyber Command, History, at https://www.cybercom.mil/About/History (noting that the planning for this Cyber Command began in 2008).

${ }^{6}$ National Defense Authorization Act for Fiscal Year 2017, Pub. L. 114-328, at $\$ 923$ (a), 130 Stat. 2000, 2357 (2016). In signing this act, President Obama stated that "Congress should leave decisions about the establishment of combatant commands to the executive branch" but noted that he "strongly support[ed] elevating [Cyber Command] to a unified combatant command." Barack Obama, Statement on Signing the National Defense Authorization Act for Fiscal Year 2017, 2016 Daily Comp. Pres. Doc. No. 863 (Dec. 23). Trump's memorandum cited to this statutory provision in elevating Cyber Command. Trump Cyber Memorandum, supra note 1.

${ }^{7}$ Lisa Ferdinando, U.S. Dep't of Defense Press Release, Cybercom to Elevate to Combatant Command (May 3, 2018), at https://dod.defense.gov/News/Article/Article/1511959/cybercom-to-elevate-to-combatant-command [https://perma.cc/U4VM-HA9A].

${ }^{8}$ U.S. Cyber Command, Mission and Vision, at https://www.cybercom.mil/About/Mission-and-Vision [https://perma.cc/95B2-PPXC].
} 
execution of their missions around the world, and strengthening our nation's ability to withstand and respond to cyber attack.

The Command unifies the direction of cyberspace operations, strengthens DoD cyberspace capabilities, and integrates and bolsters DoD's cyber expertise. USCYBERCOM improves DoD's capabilities to operate resilient, reliable information and communication networks, counter cyberspace threats, and assure access to cyberspace. USCYBERCOM is designing the cyber force structure, training requirements and certification standards that will enable the Services to build the cyber force required to execute our assigned missions. The command also works closely with interagency and international partners in executing these critical missions. ${ }^{9}$

On September 20, 2018, the Trump administration released a new National Cyber Strategy, ${ }^{10}$ the contents of which indicate an interest in increasing the military's capacity for offensive cyber operations. ${ }^{11}$ The Strategy contains four "pillars." 12 Not all of these are directly related to military cybersecurity, but the third pillar-entitled "Preserve Peace through Strength" - provides: "Cyberspace will no longer be treated as a separate category of policy or activity disjointed from other elements of national power. The United States will integrate the employment of cyber options across every element of national power." 13 The Strategy lists the following objectives for this pillar: "[i]dentify, counter, disrupt, degrade, and deter behavior in cyberspace that is destabilizing and contrary to national interests, while preserving United States overmatch in and through cyberspace." 14 The Department of Defense released a Fact Sheet alongside the Strategy that notes a few more "key themes" of the Strategy, such as "[u]sing cyberspace to amplify military lethality and effectiveness" and "[d] efending forward, confronting threats before they reach U.S. networks." 15 In a press conference announcing the Strategy, National Security Advisor John Bolton emphasized that the United States intended to "through both offensive and defensive cyber actions . . . create structures of deterrence that will reduce malign behavior in cyberspace."16

${ }^{9} I d$

${ }^{10}$ Donald J. Trump, Statement on the National Cyber Strategy, 2018 Daily Comp. Pres. Doc. No. 615 (Sept. 20) [hereinafter National Cyber Strategy Statement].

${ }^{11}$ This was also signaled earlier in the general National Security Strategy released in December 2017. Its "Cyberspace" section noted that "[w]hen faced with the opportunity to take action against malicious actors in cyberspace, the United States will be risk informed, but not risk averse, in considering our options." NATIONAL Security Strategy of the United States of America 32 (2017), available at https://www.whitehouse.gov/wpcontent/uploads/2017/12/NSS-Final-12-18-2017-0905.pdf [https://perma.cc/HAX9-HYK3].

${ }^{12}$ See generally National Cyber Strategy of the United States of America (2018), available at https://www. whitehouse.gov/wp-content/uploads/2018/09/National-Cyber-Strategy.pdf [https:/perma.cc/EDT5-GMWA].

${ }^{13} \mathrm{Id}$. at 20.

${ }^{14} I d$.

${ }^{15}$ U.S. Dep't of Defense, Fact Sheet: 2018 DoD Cyber Strategy and Cyber Posture Review (Sept. 18, 2018), available at https://media.defense.gov/2018/Sep/18/2002041659/-1/-1/1/Factsheet_for_ Strategy_and_CPR_FINAL.pdf [https://perma.cc/TA5M-5SFU].

${ }^{16}$ John Bolton, U.S. National Security Advisor, National Security Adviser John Bolton on Cyber Strategy, C-SPAN, at 5:40 (Sept. 20, 2018), at https://www.c-span.org/video/?451807-1/national-security-adviser-boltonbriefs-cyber-strategy-audio-only. In a related development one month earlier, Trump reportedly ordered the reversal of an Obama administration directive, known as Presidential Policy Directive 20 (PPD-20), which placed restrictive interagency approval requirements on any offensive cyber operation. Dustin Volz, Trump, Seeking to Relax Rules on U.S. Cyberattacks, Reverses Obama Directive, WALL ST. J. (Aug. 15, 2018), at https://www.wsj.com/ articles/trump-seeking-to-relax-rules-on-u-s-cyberattacks-reverses-obama-directive-1534378721. The Trump 
For its part, Congress signaled some support for a broader emphasis on military cyber operations in the National Defense Authorization Act for Fiscal Year 2019 (NDAA for 2019), which passed in August of 2018. Section 1636 provides that "[i]t shall be the policy of the United States . . . that the United States should employ all instruments of national power, including the use of offensive cyber capabilities, to deter ... and respond to when necessary, all cyber attacks or other malicious cyber activities of foreign powers that target United States interests." 17 Section 1642 addresses more potential threats, narrowing in specifically on Russia, China, North Korea, and Iran, and providing:

In the event that the National Command Authority determines that the Russian Federation, People's Republic of China, Democratic People's Republic of Korea, or Islamic Republic of Iran is conducting an active, systematic, and ongoing campaign of attacks against the Government or people of the United States in cyberspace, including attempting to influence American elections and democratic political processes, the National Command Authority may authorize the Secretary of Defense, acting through the Commander of the United States Cyber Command, to take appropriate and proportional action in foreign cyberspace to disrupt, defeat, and deter such attacks under the authority and policy of the Secretary of Defense to conduct cyber operations and information operations as traditional military activities. ${ }^{18}$

In addition to elevating the role of cyber operations within the military, the Trump administration has demonstrated an interest in building up the military's capabilities in space. On March 23, 2018, the White House released a fact sheet providing details on a new National Space Strategy, noting that one aim of the strategy was to "strengthen U.S. and allied options to deter potential adversaries from extending conflict into space and, if deterrence fails, to counter threats used by adversaries for hostile purposes." 19

administration has since replaced PPD-20 with National Security Presidential Memorandum 13 (NSPM-13), the text of which has not been made public, but which reportedly "frees the military to engage, without a lengthy approval process, in actions that fall below the 'use of force' or a level that would cause death, destruction or significant economic impacts." Ellen Nakashima, White House Authorizes "Offensive Cyber Operations" to Deter Foreign Adversaries, WASH. POST. (Sept. 20, 2018), at https://www.washingtonpost.com/world/national-security/ trump-authorizes-offensive-cyber-operations-to-deter-foreign-adversaries-bolton-says/2018/09/20/b5880578bd0b-11e8-b7d2-0773aa1e33da_story.html. For a more complete discussion of the broader implications accompanying the reversal of PPD-20, see Dakota S. Rudesill, Trump's Secret Order on Pulling the Cyber Trigger, LAWFARE (Aug. 29, 2018), at https://www.lawfareblog.com/trumps-secret-order-pulling-cyber-trigger.

${ }^{17}$ John S. McCain National Defense Authorization Act for Fiscal Year 2019, Pub. L. 115-232, at $₫ 1636(a)$ (2018).

${ }^{18}$ Id., $\$ 1642$ (a)(1); see also id., $\$ 1642$ (d) (providing that this section should not be "construed to ... affect the War Powers Resolution”). The remaining provisions of the NDAA addressing cyberspace-related matters tend to be more administrative in nature. For an expanded discussion regarding these provisions, see Robert Chesney, The Law of Military Cyber Operations and the New NDAA, LAwFARE (July 26, 2018), at https://www.lawfareblog.com/ law-military-cyber-operations-and-new-ndaa.

${ }^{19}$ White House Fact Sheet, President Donald J. Trump Is Unveiling an America First National Space Strategy (Mar. 23, 2018), at https:/www.whitehouse.gov/briefings-statements/president-donald-j-trump-unveiling-america-first-national-space-strategy [https://perma.cc/BS5N-6M9Z]. The executive branch has not released the actual text of the strategy. The issuance of this fact sheet came shortly after a deadline - set by the National Defense Authorization Act for Fiscal Year 2018-for the Department of Defense to produce an interim report with recommendations for reforming the "organizational and management structure for the national security space components of the Department of Defense." National Defense Authorization Act for Fiscal Year 2018, Pub. L. 115-81, at $\$ 1601$ (c) (2017). 
On June 18, 2018, noting that "it is not enough to merely have an American presence in space, [the United States] must have American dominance in space," Trump "direct[ed] the Department of Defense and Pentagon to immediately begin the process necessary to establish a Space Force as the sixth branch of the armed forces." 20 Two months later on August 9, Vice President Pence delivered a speech at the Pentagon regarding national security and space. Justifying the need for a Space Force, he noted that "our adversaries have been working to bring new weapons of war into space itself." ${ }^{21} \mathrm{He}$ specifically referenced actions by Russia and China, including China's 2015 "creat[ion of] a separate military enterprise to oversee and prioritize its warfighting capabilities in space." 22

Released the same day as Pence's speech, a report by the Department of Defense made clear that some changes would be undertaken by the executive branch but that "[e]stablishing a sixth branch of the Armed Forces requires Congressional action." 23 With respect to steps that could be taken by the executive branch:

First, DoD will establish a Space Development Agency to develop and field space capabilities at speed and scale. The Air Force has already begun to transform its Space and Missile Center (SMC). The Department will accelerate and extend this transformation to all services by creating a joint Space Development Agency.

Second, the Department will develop the Space Operations Force to support the Combatant Commands. These joint space warfighters will provide space expertise to combatant commanders and the Space Development Agency, and surge expertise in time of crisis to ensure that space capabilities are leveraged effectively in conflict.

Third, the Department will create the governance, services, and support functions of the Space Force. Many of these will require changes to U.S. law. The Department will build a legislative proposal for Congressional consideration as a part of the Fiscal Year 2020 budget cycle.

Fourth, the Department will create a U.S. Space Command, led by a four star general or flag officer, to lead the use of space assets in warfighting and accelerate integration of space capabilities into other warfighting forces. U.S. Space Command will be responsible for directing the employment of the Space Force. ${ }^{24}$

${ }^{20}$ Associated Press, Trump Announces Creation of "Space Force," YouTuBE (June 18, 2018), available at https:// www.youtube.com/watch?v=Kna3YYX7XeE. Presently, in addition to the Army, the Navy, and the Air Force, the other two branches are the Marine Corps, which is formally lodged within the Navy, and the Coast Guard, which is currently situated within the Department of Homeland Security.

${ }^{21}$ White House Press Release, Remarks by Vice President Pence on the Future of the U.S. Military in Space (Aug. 9, 2018), at https://www.whitehouse.gov/briefings-statements/remarks-vice-president-pence-future-usmilitary-space.

${ }^{22} \mathrm{Id}$.

23 U.S. Dep't of Defense, Final Report on Organizational and Management Structure for the National Security Space Components of the Department of Defense 4 (2018), available at https://media. defense.gov/2018/Aug/09/2001952764/-1/-1/1/organizational-management-structure-dod-national-securityspace-components.pdf [https://perma.cc/D8EF-KL94].

${ }^{24} I d$. at 7 . The report goes into further detail about all four of these components, including individual timelines, goals, and developmental priorities. Id. at 8-13. Space Command had previously existed as a Unified Combatant Command from 1985 to 2002, but its duties were thereafter folded within Strategic Command, another Unified Combatant Command, when military focus turned to combatting terrorism and improving homeland security 
With respect to the final action step-the establishment of a U.S. Space Command-it remains unclear whether this will result in an eleventh Unified Combatant Command (in addition to Cyber Command and the nine other existing ones) or will instead be lodged within the existing U.S. Strategic Command. The NDAA for 2019 had instructed the Department of Defense to establish U.S. Space Command as a subordinate unified command within U.S. Strategic Command. ${ }^{25}$ On December 18, 2018, however, Trump issued a memorandum to "direct the establishment, consistent with United States law, of United States Space Command as a functional Unified Combatant Command." 26 The executive branch has requested that Congress repeal the just-mentioned language from the NDAA for 2019 so that there will be no impediment to making U.S. Space Command into a Unified Combatant Command. ${ }^{27}$

The Trump administration is also pursuing legislation to make the Space Force the sixth branch of the armed services. ${ }^{28}$ On March 1, 2019, the Department of Defense proposed such legislation to Congress. Rather than creating the Space Force as a wholly independent branch, the proposal places the Space Force within the Air Force, akin to how the Marine Corps sits within the Navy. ${ }^{29}$ Although Trump had originally envisioned the Space Force as an entirely independent military branch, ${ }^{30}$ earlier in the spring he had signaled his openness to this nested placement as an initial step. ${ }^{31}$ Reception to the proposal in Congress has been mixed to date, ${ }^{32}$ and most recently lawmakers have

following the September 11, 2001 attacks. Gary Shugart, Re-establishing U.S. Space Command, PurviEw (Oct. 1, 2018), at http://purview.dodlive.mil/2018/10/01/reestablishing-u-s-space-command.

${ }^{25}$ John S. McCain National Defense Authorization Act for Fiscal Year 2019, Pub. L. 115-233, at $\$ 1601$ (a)(1) (2018).

${ }^{26}$ Donald J. Trump, Memorandum on Establishment of United States Space Command as a Unified Combatant Command, 2018 Daily Comp. Pres. Doc. No. 855 (Dec. 18); see also U.S. Dep't of Defense Press Release, United States Space Command Commander Announced (Mar. 26, 2019), at https://dod. defense.gov/News/News-Releases/News-Release-View/Article/1796472/united-states-space-command-commander-announced [https://perma.cc/36H3-RUDU] (stating that Trump has nominated a commander for the future Space Command).

${ }^{27}$ Marcus Weisberber, Legislative Hurdle Delays US Space Command Stand-Up, Defense One (Feb. 28, 2019), at https://www.defenseone.com/politics/2019/02/legislative-hurdle-delays-us-space-command-stand/155220.

${ }^{28} \mathrm{Jim}$ Garamone, U.S. Dep't of Defense Press Release, DOD Sends Space Force Legislation to Congress (Mar. 1, 2019), at https://dod.defense.gov/News/Article/Article/1771782/dod-sends-space-force-legislation-to-congress [https://perma.cc/YU43-JKHF]; see also U.S. Dep’t of DefEnse, United STATES Space Force LegisLative Proposal (Mar. 1, 2019), available at https://media.defense.gov/2019/Mar/01/2002095010/-1/-1/1/UNITEDSTATES-SPACE-FORCE-LEGISLATIVE-PROPOSAL.PDF [https://perma.cc/2BHT-NC67] [hereinafter Space Force Proposal].

${ }^{29}$ Space Force Proposal, supra note 28, at 2. The rationale behind this decision is a consideration for not generating unnecessary costs. U.S. Dep't of Defense Press Transcript, Off-Camera Press Briefing in the Pentagon Briefing Room (Jan. 29, 2019), at https://dod.defense.gov/News/Transcripts/Transcript-View/ Article/1743317/off-camera-press-briefing-in-the-pentagon-briefing-room [https://perma.cc/JJD6-KGZE].

${ }^{30}$ Even as late as November 29, 2018, the White House was reportedly committed to an entirely independent Space Force. Jacqueline Klimas, Trump Going for Full-Blown Space Force, White House Memo Reveals, Politico (Nov. 29, 2018), at https://www.politico.com/story/2018/11/29/space-force-military-branch-999528.

${ }^{31}$ See Donald J. Trump, Memorandum on Establishment of the United States Space Force, 2019 DAILY ComP. Pres. Doc. No. 88 (Feb. 19) (defining "United States Space Force" as a new military branch "to be initially placed by statute within the Department of the Air Force") (emphasis added).

32 See Senate Armed Services Committee, Executive Summary of Proposed FY 2020 National Defense Authorization Act, available at https://www.armed-services.senate.gov/imo/media/doc/FY\%202020\%20NDAA \%20Executive\%20Summary.pdf (proposing legislation that would create a Space Force within the Air Force in line with the suggestion of the Department of Defense); Sandra Erwin, HASC Chairman Rejects Trump's Space 
informed Acting Defense Secretary Patrick Shanahan that more budget details are needed for the Space Force, as well as for U.S. Space Command and the Space Development Agency. ${ }^{33}$

The U.S. military restructuring with respect to cyber operations and space does not directly implicate issues of international law. To the extent that this reshuffling results in operational actions, however, it remains to be seen how such actions will fit into the existing international legal framework. International law on the use of force and international humanitarian law are generally applicable. The specifics of how these laws apply to cyber operations have been the subject of considerable interest, with the Tallinn Manual 2.0 often looked to as the most significant piece of work on the subject to date. ${ }^{34} \mathrm{With}$ respect to space, the United States is a party to the Outer Space Treaty, which bans certain military actions in space, ${ }^{35}$ and there are other sources of law specifically focused on space that are potentially relevant as well. ${ }^{36}$

\section{SETTLEMENT OF DisPuTES}

The United States Resolves Its Request for Consultations Regarding Peru's Environmental Obligations Under Bilateral Trade Agreement

doi:10.1017/ajil.2019.40

On April 9, 2019, the United States and Peru reached a resolution regarding concerns about Peru's forest sector obligations under the 2007 United States-Peru Trade

Force Proposal, Says Committee Will Seek “Other Options, ”SpaceNews (Mar. 25, 2019), at https://spacenews.com/ hasc-chairman-rejects-trumps-space-force-proposal-says-committee-will-seek-other-options (reporting on House Armed Services Committee Chairman Adam Smith's opposition to the Space Force proposal).

${ }^{33}$ Sandra Erwin, House Appropriators Press for Details on Space Force Cost and Organization, SpaceNews (May 1, 2019), at https://spacenews.com/house-appropriators-press-for-details-on-space-force-cost-and-organization.

34 Tallinn Manual 2.0 on the International Law Applicable to Cyber Operations (Michael N. Schmitt ed., 2d ed. 2017); see also Dan Efrony \& Yuval Shany, A Rule Book on the Shelf? Tallinn Manual 2.0 on Cyberoperations and Subsequent State Practice, 112 AJIL 583 (2018) (assessing the extent to which states to date have accepted the rules set out in the Tallinn Manual); Eric Talbot Jensen, The Tallinn Manual 2.0: Highlights and Insights, 48 GEO. J. INT'L LAW 735 (2017) (discussing some of the key points from Tallinn 2.0). For a recent perspective on how the Department of Defense may be approaching these issues, see Michael J. Adams \& Megan Reiss, International Law and Cyberspace: Evolving Views, LAWFARE (Mar. 4, 2018), at https://www.lawfareblog.com/international-law-and-cyberspace-evolving-views (also noting that the "U.S. government . . . has taken no official position on the views set forth in the [Tallinn] Manual").

35 Treaty on Principles Governing the Activities of States in the Exploration and Use of Outer Space, Including the Moon and Other Celestial Bodies, at Art. 4, Jan. 27, 1967, 18 UST 2410, 610 UNTS 205 (prohibiting treaty parties from putting "nuclear weapons or any other kinds of weapons of mass destruction" into orbit or onto celestial bodies).

36 See Matthew T. King \& Laurie R. Blank, International Law and Security in Outer Space: Now and Tomorrow, 113 AJIL Unbound 125, 127-29 (2019) (discussing the application of international law to military space operations). 